\title{
Improving Environmental Quality of Margoon Waterfall Protected Area through Sustainable Tourism Development in the Region
}

\author{
Dr. Mohammadreza Bemanian \\ Department of Architecture, Faculty of Art, University of Tarbiat Modares \\ Jalal Ale Ahmad St, Tehran, Iran \\ Tel: 98-91-2108-1534_E-mail: bemanian@modares.ac.ir \\ Ferial Ahmadi (Corresponding author) \\ Department of Architecture, Faculty of Art, University of Tarbiat Modares \\ Jalal Ale Ahmad St, Tehran, Iran \\ Tel: 98-91-7311-0375 E-mail: f_ahmadi@modares.ac.ir \\ Alireza Sadeghi \\ Department of Architecture, Faculty of Art, University of Tarbiat Modares \\ Jalal Ale Ahmad St, Tehran, Iran \\ Tel: 98-91-7314-6514_E-mail: arsadeghi@modares.ac.ir \\ Afsaneh Baharlou \\ Shiraz University, Eram St. Shiraz. Iran \\ Tel: 98-91-7315-9997_E-mail: afsoonbahar1@yahoo.com
}

\begin{abstract}
The protected area of Margoon Waterfall is the obvious manifestation of special ecological, environmental, economic, social, cultural and historical features and tourist attractions. Now the lack of compatibility between the capacity of the region and the number of tourists has endangered the area. So, this research has been formed to develop sustainable tourism of this region.

In the current research, survey method in descriptive - analytic ways have been applied. In order to access treats, opportunities, weak and strong points of Margoon waterfall, first, reasonable documents such as maps and photos of the region have been studied and analyzed. Then tourist's priorities for the presence in the area have been scrutinized by preparation questionnaire. Finally, compatibility between tourist's priorities and natural attractive of the region has been measured in order to delete incompatible activities from vicinity of natural attraction of the bed and present suggestion for sustainable tourism development patterns of protected landscape of Margoon waterfall.
\end{abstract}

Keywords: Natural Landscape, Sustainable tourism, Protected Areas

\section{Introduction, research validity and methods}

Bearing in mind the fact that natural landscapes have been the manifestation of culture and civilization as well as a means for the formation of man's identity and his most exalted accomplishments for a long time, it seems that a great bond between cities and nature and their natural landscapes can bring about liveliness and dynamism in human societies. Landscapes formed the narratives of our antecedents' collective, individual and cultural memories. Therefore, due to the acceleration of the destruction process and decline in man's main natural resources, it is now much more necessary than at any other time to apply sustainable principles in order to prevent the destruction process of natural landscapes and scenery. It is important to organize these identity-bringing areas in the form of sustainable design.

One of the outcomes of paying attention to natural areas as well as employing sustainable principles in organizing them would be the attraction of various social groups and the development of tourism in these areas. It is also seems that using sketches of sustainable design in organizing natural landscapes and scenery can help reduce the problems and difficulties of tourism, because, in fact, the ultimate goal of sustainable design is to provide conditions in which one can make use of environmental potential and enhance the quality of the environment. It is obvious that improvement in the quality of environment will provide appropriate situations for tourist attraction, thus reaching the concept of sustainable tourism.

The research method of the present study is that of a descriptive-analytic survey, the objective of which is to present patterns of sustainable tourism development for the protected landscape of the Margoon Waterfall area. First, the researchers tried to distinguish shortcomings, strengths and potential attractions of the area through an accurate understanding of the bio-environmental, economic, social, historical and cultural variables of the place 
and then analyze that information by means of cogent documents and evidence. Second, inbound and outbound tourists' reasons for coming to the natural landscapes of the waterfall were studied and evaluated through procedures of observation, interview and questionnaires. Members of the local indigenous community of the region were also submitted to these methods. Finally, the patterns of sustainable tourism development in the Margoon Waterfall protected landscape were investigated by means of evaluating the compatibility of the tourists' reasons for visiting the protected Margoon site against the natural attractions of the area such as special vegetation, the waterfall and the river as well as topography.

This study will first review the concepts of protected area. Second, the dimensions and objectives of sustainable tourism development will be described and analyzed. Furthermore, this study will introduce the protected area of Margoon Waterfall as a case study, look into its features and find out the preferences of visitors coming to the area. Finally, evaluating this protected area with respect to the visitors' and tourists' preferences for coming and with regard to its natural attractions, the sustainable tourism development patterns for the protected Margoon landscape are presented, applying the principles of sustainable tourism development.

\section{Literature review}

A protected area is a clearly defined geographical space, managed - through legal or other effective means- to achieve the long-term conservation of nature and associated cultural values (IUCN, 2008, p.19). In fact, these areas represent the greatest heritage that can be passed down to the following generations. They are meant to guarantee posterity's access to nature and the benefits accrued from it on the one hand and to protect the biological, cultural and environmental variety of natural areas on the other. IUCN divides the protected areas into six categories: (1) strict nature reserve and wildness areas, (2) national parks, (3) natural monuments, (4) habitat/species management, (5) protected landscape/seascape and (6) protected areas with sustainable use of natural resources. Iran Department of the Environment has presented a four-category framework: (1) national parks, (2) natural monuments, (3) protected landscapes and (4) wildlife resorts. The definitions and objectives in each of the protected areas presented by these two organizations have been set out in table 1.

Table 1. Objectives in Each Protected Area. Reference: Authors.

\subsection{Sustainable tourism development}

According to the World Tourism Organization, tourism is the collection of activities that a person does while visiting a place other than their ordinary environment for not less than 24 hours and not more than a year and for purposes such as leisure, recreation, relaxation, sport, meeting family and friends, business, attending conferences, health, study and research, religion and similar activities. (Rezvani, 2008, p.4)

Guel Kohan believes that due to special technology of its own, the tourism industry provides a motor by which the wheels of other vital industries such as transportation, construction, food production, export industries etc. can be accelerated, paving the way for local and national development. The special technology of this industry consists of four essential elements: the instruments and equipment of human force, information/communication, organization and management. (1998, p. 80) As with other industries, in spite of the importance of the tourism industry to the national and international economy, one should not ignore the basic problems caused by its growth. Difficulties such as socio-cultural contradictions, environmental side-effects and destruction of natural resources vary in different countries and change according to economic, environmental and social conditions, much as positive affects do. (Kohan, 1998, p. 80) Tourism has different goals and recognizing them is important in realizing tourists' incentives. Different types of tourism have been studied from disparate points of view, as shown in table 2 .

Table 2. Different Types of Tourism from the Experts' Points of View (Aspects of Sustainable Tourism Development) References: Authors

Nowadays, one of the most important concerns of designers in introducing a tourism development design is making one that can provide a sustainable balance between tourists' presence and benefit to the environment. It is obvious that tourism development which exceeds capacity causes the destruction of habitats and natural ecosystems on the one hand, and reduces local communities' tolerance on the other. Therefore, sustainable tourism is a kind of tourism which aims at the management of renewable resources, that is, human or natural resources, in a way that can both satisfy tourists' economic, social and aesthetic demands and maintain cultural solidarity, essential ecological processes, ecological variety and natural systems (WTO, cited in Rezvani, 2008, p. 20). In fact, sustainable tourism deals with tourism activities that satisfy present tourists' demands without threatening the possibility of satisfying future tourists' demands (Weaver, cited in Rezvani, 2008, p.20). Thus, sustainable tourism development emphasizes local community development, improving the supply chain of local products, encouraging local industries and occupations, fostering development according to bio, environmental and social capacity and increasing the stability of tourism income (Rezvani, 2008, p.119). In table 3 , general dimensions and goals of sustainable tourism development are shown.

Table 3. Aspects of Sustainable Tourism Development. References: Authors 
It is important to mention that tourist attractions are divided into two groups: natural and human resources and attractions. Natural factors such as climatic conditions, wildlife habitats, natural vegetation and historical, tribal and cultural features are effective in attracting inbound and outbound tourists. Therefore, in the process of sustainable tourism development, one should organize attractions to encourage tourists to come to the region more, as well as protect the cultural, historical, social and ecological value of the area.

Figure 1. Attainment Process of Sustainable Tourism Development. References: Authors

\section{Margoon Waterfall protected area}

The protected region of Margoon Waterfall is located in the northwest of the Fars province, $128 \mathrm{~km}$ from Shiraz. It is between 30 and 31 in width and 51 and 52 in length. It is 10,000 hectares in size. This area was proclaimed a protected area through Legislation 192 of the Environment Protection Council, a conservation organization, in 1999. The region is surrounded by the Barmandili Mountains in the east, Galakeh in the west, the Komhar Mountains in the south and the village of Jobkhaleh in the north. The only village in the protected region itself is Margoon, which is located to the northwest of Margoon Waterfall and is $2 \mathrm{~km}$ from the fall. This region has a cold, mild climate with enough rain (Sharghayand Consulting Engineers, 2007, p. 21). It is important to mention that the water exiting point is 2200 meters above sea level and the top of the waterfall is 60 meters high. The height of the Margoon valley from which the waterfall flows is 117 meters. The waterfall is the origin of the Margoon river, which joins the Jobkhaleh river and forms one of the major sources of the Kor river.

\subsection{Natural attractions of the Margoon Waterfall protected area \\ - Plant communities}

Plants and trees of the region are divided into three groups:

1. Pistachio and almond which are seen at 2,800 meters above sea level and include acer sp, celtis sp, barberry and sumac.

2. Acorn, which grows up to 2,500 meters above sea level and includes celtis sp, crataegus, acer sp, fig, turpentine, plane, willow, walnut and pistachio.

3. Plants in land under cultivation, which includes farming fields and fruit gardens.

\section{- Wildlife}

Animal variety of Margoon Protected Area can be divided into three groups:

1. Birds such as the partridge, grouse, dull-yellow partridge, pigeon, ringdove, starling, sparrow, falcon and eagle.

2. Aquatic animals and fish.

3. Mammals such as the deer, ewe, goat, bear, marten, wolf, jackal, hyena, rabbit and boar.

\section{- $\quad$ Water resources}

Margoon Waterfall is located at a longitude of 53 degrees east and a latitude of 30 degrees north. The water exiting point is 2,200 meters above sea level and the highest part of the fall is 60 meters. The water of the fall originates from the Ranj and Barm Firouz Mountains and the resources of the watershed. The highest point of the Margoon Valley from which the waterfall flows is 117 meters. Margoon Waterfall is the origin of the Margoon river that joins the Jobkhaleh rivers and forms one of the major origins of Kor river (Shargh Ayand Consulting Engineers, 2007, p.24).

\section{- Topography and slopes}

The part of Margoon Waterfall which is the completely protected area and contains the most sensitive natural value of the region (the area of Margoon Waterfall and the riverside grove) has 70 degree slopes. In addition, a great part of the protected site includes land with 5 degree slopes as well as spare jungle vegetation. Due to the overgrazing of livestock, these lands have faced erosion and decline. Also, there are some slopes of 10 to 50 percent in other parts of this area which are under cultivation or are fruit gardens and pasturelands. Figure 2 shows the location of natural views and use of the existing lands in the protected region of Margoon Waterfall.

Figure 2. Current Use of the Protected Region of Margoon Waterfall. References: Authors

It is obvious that the natural attractions of this region have paved the way for more tourist presence. However, the lack of compatibility between the capacity of the region and the number of tourists has endangered the area. Table 4 evaluates the current situation of the region to come into the designing patterns of sustainable tourism development of the Margoon protected area.

Table 4. The Current Situation of the Margoon Protected Area. References: Authors

\section{Reasons for choosing the protected area of Margoon Waterfall for recreation by tourists}

Since the basic goal in presenting sustainable tourism development designs is to satisfy tourists' demands as well as to maintain cultural, social, historical, ecological and economic values, reasons for tourists' choice of the protected area of Margoon Waterfall were analyzed and evaluated by designing a questionnaire. This way, 
sustainable tourism patterns of Margoon Waterfall can be based on inbound and outbound tourist preferences. The analysis of collected data indicates that tourists come to the protected site of Margoon Waterfall to enjoy exciting natural phenomena - such as the Margoon river and oak jungles and the waterfall itself - as well as to go camping, fishing, hunting, mountain climbing, walking, wandering in the jungle, watching the local wildlife and doing cooperative activities and aquatic sports. Tourists' ideas about the importance of the aforementioned recreational activities - divided into categories of wide-spread, concentrated and sport activities - are presented in figure 3. In addition, descriptive statistics and demographic characteristics such as age, sex and marital status are analyzed and evaluated in table 5.

Table 5. Descriptive Statistics \& Demographic Characteristics. References: Authors

Figure 3. Tourists' Reasons for Presence in Margoon Site According to Their Ideas. References: Authors

\section{Summary}

Considering the results obtained through the analysis and evaluation of the gathered data and questionnaires, the facilities and services necessary for greater tourist presence in the region under study are divided into three groups: (1) recreation and sport facilities (camping, cooperative sports, walking, fishing, jungle wandering, hunting, mountain and water sports), (2) welfare and (3) residential and training services. The matrix presented in table 6 indicates the degree of compatibility of each of the aforementioned tourist facilities with natural attractions of the protected site of Margoon Waterfall (topography and slopes, vegetation, wildlife and water resources). It is important to state that the site of Margoon Waterfall is categorized as natural monuments according to the classification presented by the IUCN; however, the Iran Department of the Environment classified it as a protected area. Therefore the degree of compatibility between the facilities required by tourists and the natural attractions of the area has been studied, emphasizing the protective patterns presented by the IUCN in regard to natural monuments, as well as those of the Iran Department of the Environment. In all of the aforementioned patterns, great emphasis is put on maintaining the equilibrium among natural and cultural ecosystems through expanding management plans to retain all social, cultural, traditional and spiritual values of the area and reach sustainable design patterns.

Table 6. Rate Capability between Recreational \& Educational Facilities and Services with the Natural Attraction of Margoon Protected Area. References: Authors

\section{Conclusion}

The protected area of Margoon Waterfall is the obvious manifestation of special ecological, environmental, economical, social, cultural and historical features and tourist attractions that can change it into a symbol of sustainability in the region if it satisfies present tourists' demands. Incompatibility between some of the tourists' needs and preferences - such as hunting, fishing, camping and residential services - and natural attractions of the area are investigated in table 7. This incompatibility has caused problems such as decline in some species, erosion of valleys and destruction of plants growing near the river, severe noise and weather pollution due to the disruptive presence of vehicles in the special protected area, depletion of the Zagros jungles due to overgrazing of animals from local communities, camping and tourist neglect in participating in conservation of the area. Tourism development is one of the bases of sustainable development in communities. Therefore, suggestions and patterns for sustainable tourism development in the Margoon protected area based on the expansion of sustainable landscape design principles are presented in table 7.

Table 7. Suggestion for Sustainable Tourism Development in the Margoon Waterfall Protected Area. References: Authors

It is expected that paying attention to the stated suggestions and employing them in the protected site of Margoon Waterfall will pave the way for sustainable tourism development in this natural area.

\section{References}

Ahmadi, F. (2009). Landscape Designing Principles in Natural Waterfall Landscapes: Case Study: Margon Waterfall Protected Area. M.A thesis on Tarbiat Modares University. Supervisor: Dr.M.R.Bemanian. advisor: Dr.A.M.Moradi

Benson, F \& Maggie. (2000). Landscape and Sustainability. London, the UK, Spon Press

Behbahani,H \& Sharifi, A. (2003). A Glance At The Conservation And Reclamation Of Archeological Landscape (case study: Takht - e Soleyman) Iranian Architecture Journal. vol 3 . N. 12+13

Behbahani,H \& Razi Moftakhar, N. ( 2005). Sustainable Design Of Sheikh Tapeh Forest Park, Urmiah. Environmental studies Journal. vol 1

Bell, S. (2003). Landscape, Pattern, Perception And Process. Translated from English into Persian by B. Aminzadeh. Tehran: Tehran University Press

Botkin,D \& Keller, E. (2003). Environmental Science. Translated from English into Persian by A. Vahabzadeh. Mashhad: Mashhad University Press

Carmona, M. (2003). Public places, urban spaces. Architectural press 
Charles, A. (1999). Protecting Cultural Landscapes. USA. National Park Service.

Golkar, k. (2001). Manufacturer Components of Quality in Urban Design. Sofeh journal. Vol32

Mikyoung (1989) The determinants of residential environmental qualities and satisfaction: Toward developing residential quality indices. PhD-Thesis, Oklahoma State University.

Harg, L. (2007). Design with Nature. Translated from English into Persian by A. Vahabzadeh. Mashhad: Mashhad University Press

Harker, D. \& Evans, L. (1999). Landscape Restoration (Hand Book). Lewis Publisher

Institute of Environmental Management and Assessment (2002) Guidelines for Landscape and Visual Impact Assessment. Translated from English to Persian by M.Tabibian, Tehran University publication.

IUCN Report. (2008). Implementing Sustainable Bioenergy Production (A Compilation of Tools and Approaches. Retrived June 8, 2009, from http://www.iucn.org/publications.

IUCN Report. (2006). Guidelines for applying protected area management categories. Retrived June 8, 2009, from http://cmsdata.iucn.org.

Khorasanizadeh, M. (2003). Issue on Understanding Landscape Architecture . Iranian Architecture Journal. vol 3. N. $12+13$

Kohan, G. (1998). Tourism industry and sustainable development symbolizes the dynamic management. Journal of Environmental Studies. vol 21

Madanipour, A. (2005). Design Of Urban Space: inquiry into a socio - spatial process. Translated from English to Persian by F. Mortezaiee. Tehran: Pardazesh publication.

Majnoonian,H. ( 1995). Discussions about the parks, green spaces. Tehran parks and green space organization press

Matlak, J. (2000). Introduction to Environmental Design and Landscape. Translated from English into Persian by Tehran parks and green space organization

Mccarthy, B. (2003). Sustainable Landscape. Iranian Architecture Journal. vol 3. N. 12+13

Pakzad, J. (2007). Theoretical Basics and Process of Urban design. $2^{\text {nd }}$ ed. Tehran: Shahid Beheshti University Publications, In Persian.

Parvinian, M. (2003). Re - Creation Of Land: The Reclamation And Revival Of Landscape. Iranian Architecture Journal. vol 3. N. $12+13$

Rezvani, M. (2003). Rural Tourism Development ( Sustainable Tourism Approach). Tehran: Tehran University Press

Spirn, A. W. (2005). The Language of Landscape. Translated from English into Persian by H. Bahreini, B. Aminzadeh. Tehran: Tehran University Press (Originally Published in 2000)

Tabibian, M. (1999). Sustainable Indicators and Their Implication in the Environment. Journal of Environmental Studies. vol 24

Sharghayand Consulting Engineers. (2007). Abstract Margoon Tourism Development Master Plan. Cultural Heritage Organization

Van Kamp, Irene and et al. (2003). Urban Environmental quality and human well-being Toward a conceptual framework and demarcation of concepts: a literature study. Landscape and Urban Planning. vol 65, pp. 5-18.

World Restoration Institute Report. (2000). Ecological Restoration and Rehabilitation. USA.

Note:

"This paper has been extracted from the theoretical basics of M.A thesis of Ferial Ahmadi entitled "Landscape Designing Principles in Natural Waterfall Landscapes: Case Study: Margon Waterfall Protected Area" with guidance of Dr. M.R. Bemanian in Tarbiat Modares University. 
Table 1. Objectives in Each Protected Area. Reference: Authors

\begin{tabular}{|c|c|c|}
\hline $\begin{array}{l}\text { Prote } \\
\text { cate }\end{array}$ & Conservation principles & Rehabilitation principles \\
\hline $\begin{array}{l}\text { Strict nature } \\
\text { reserve and } \\
\text { Wilderness area }\end{array}$ & $\begin{array}{l}\text { To conserve regionally, nationally or } \\
\text { globally outstanding ecosystems, } \\
\text { species (occurrences or aggregations) } \\
\text { and/or geo-diversity features: these } \\
\text { attributes will have been formed } \\
\text { mostly or entirely by non-human } \\
\text { forces and will be degraded or } \\
\text { destroyed when subjected to all but } \\
\text { very light human impact. } \\
\text { ( IUCN,2006, p.14) }\end{array}$ & 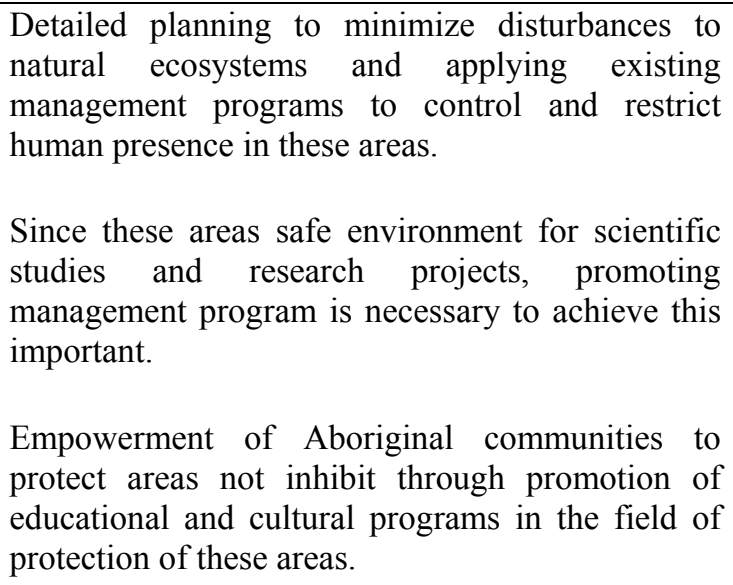 \\
\hline National park & $\begin{array}{l}\text { To protect natural biodiversity along } \\
\text { with its underlying ecological } \\
\text { structure and supporting } \\
\text { environmental processes, and to } \\
\text { promote education and recreation. } \\
\text { ( IUCN,2006, p.16) }\end{array}$ & $\begin{array}{l}\text { To manage visitor uses of these areas for } \\
\text { educational and recreational purposes. } \\
\text { To promote educational and recreational programs } \\
\text { in these areas to be not lead to decline of natural } \\
\text { resources. }\end{array}$ \\
\hline $\begin{array}{l}\text { Natu } \\
\text { monu }\end{array}$ & $\begin{array}{l}\text { To protect specific outstanding } \\
\text { natural features and their associated } \\
\text { biodiversity and habitats. } \\
(\text { IUCN,2006, p.17) }\end{array}$ & $\begin{array}{l}\text { To promote training programs in the identification } \\
\text { and protection of historical, natural and spiritual } \\
\text { values of natural or cultural landscapes. }\end{array}$ \\
\hline $\begin{array}{r}\text { Habitat } / \mathbf{s} \\
\text { manage } \\
\text { are }\end{array}$ & $\begin{array}{l}\text { To maintain, conserve and restore } \\
\text { species and habitats. ( IUCN,2006, } \\
\text { p.19) }\end{array}$ & $\begin{array}{l}\text { To develop general education in the protection of } \\
\text { species and habitats. }\end{array}$ \\
\hline $\begin{array}{l}\text { Protected } \\
\text { landscape/ } \\
\text { seascape }\end{array}$ & $\begin{array}{l}\text { To protect and sustain important } \\
\text { landscapes/seascapes and the } \\
\text { associated nature conservation and } \\
\text { other values created by interactions } \\
\text { with humans through traditional } \\
\text { management practices. ( IUCN,2006, } \\
\text { p.20) }\end{array}$ & $\begin{array}{l}\text { To present natural products and environmental } \\
\text { services } \\
\text { To present the framework and principles in order } \\
\text { to achieve active human intervention in natural } \\
\text { landscapes. } \\
\text { To present opportunities promenade and Tourism } \\
\text { and the required facilities in this area }\end{array}$ \\
\hline $\begin{array}{l}\text { Protected area } \\
\text { with } \\
\text { sustainable use } \\
\text { of natural } \\
\text { resources }\end{array}$ & $\begin{array}{l}\text { To protect natural ecosystems and } \\
\text { use natural resources sustainably, } \\
\text { when conservation and sustainable } \\
\text { use can be mutually beneficial. } \\
\text { ( IUCN,2006, p.22) }\end{array}$ & $\begin{array}{l}\text { To promote educational programs in the sustainable } \\
\text { use of natural resources regarding all aspects of } \\
\text { social, ecological and economic } \\
\text { To facilitate security in local communities, tourism } \\
\text { activities, scientific research and research } \\
\text { To assistance to sustainable development in } \\
\text { national, regional and local practice training, } \\
\text { cultural and management in this area }\end{array}$ \\
\hline
\end{tabular}


Table 2. Different Types of Tourism from the Experts' Points of View (Aspects of Sustainable Tourism Development) References: Authors

\begin{tabular}{|c|c|c|}
\hline \multirow{6}{*}{ Valen Smith } & Tribal tourism & $\begin{array}{l}\mathrm{n} \text { this kind of tourism, tourist travel to observe local people and tribes } \\
\text { lifestyle. }\end{array}$ \\
\hline & $\begin{array}{l}\text { Artistic } \\
\text { tourism }\end{array}$ & $\begin{array}{l}\text { In this kind of tourism, tourists like to learn other people and nation nations } \\
\text { art. }\end{array}$ \\
\hline & $\begin{array}{l}\text { Historical } \\
\text { tourism }\end{array}$ & This tourists visit museums, mosques churches and historical monument. \\
\hline & $\begin{array}{l}\text { Naturalistic } \\
\text { tourism }\end{array}$ & $\begin{array}{l}\text { A naturalistic tourism pays attention to natural and environmental } \\
\text { attractions, they shelter in the beautiful nature and admire natural } \\
\text { attractions. }\end{array}$ \\
\hline & $\begin{array}{c}\text { Convention } \\
\text { tourism }\end{array}$ & $\begin{array}{l}\text { This kind of tourism does not aim at recreation and pleasure but vocational } \\
\text { watching. }\end{array}$ \\
\hline & $\begin{array}{l}\text { Recreational } \\
\text { tourism }\end{array}$ & $\begin{array}{l}\text { recreational and sport tourism is concerned with participation in athletic } \\
\text { and social activities. }\end{array}$ \\
\hline \multirow{7}{*}{$\begin{array}{l}\text { Chuck } \\
\text { Y. Gee }\end{array}$} & $\begin{array}{l}\text { Travel for } \\
\text { watching }\end{array}$ & Such tourists tend to visit physical environments and go there for watching. \\
\hline & $\begin{array}{l}\text { Cultural } \\
\text { tourism }\end{array}$ & $\begin{array}{l}\text { is concerned with that part of tourism industry which pays attention to } \\
\text { cultural attractions. }\end{array}$ \\
\hline & Rural tourism & It includes visiting rural areas for cultural and adventurous purposes. \\
\hline & $\begin{array}{l}\text { Adventure } \\
\text { tourism }\end{array}$ & $\begin{array}{l}\text { Perilous or adventurous trips to dangerous destinations such as deserts, } \\
\text { jungles, rivers and ete are called advanture tourism. }\end{array}$ \\
\hline & $\begin{array}{l}\text { Modern } \\
\text { tourism }\end{array}$ & $\begin{array}{l}\text { It includes trips with cultural, sanitation and watching natural sights } \\
\text { purposes. }\end{array}$ \\
\hline & $\begin{array}{l}\text { Educational } \\
\text { tourism }\end{array}$ & $\begin{array}{l}\text { It includes trips in which travels learn some things thorough a formal and } \\
\text { systemic plan. }\end{array}$ \\
\hline & $\begin{array}{l}\text { Commercial } \\
\text { tourism }\end{array}$ & $\begin{array}{l}\text { This trips include conferences, rewards, organizational sessions and } \\
\text { exhibitions. }\end{array}$ \\
\hline
\end{tabular}


Table 3. Aspects of Sustainable Tourism Development. References: Authors

\begin{tabular}{|c|c|c|}
\hline $\begin{array}{l}\text { Aspects } \\
\text { sustainable } \\
\text { tourism }\end{array}$ & Definitions & Goals \\
\hline \multirow{3}{*}{$\begin{array}{c}\text { Ecological } \\
\text { sustainability }\end{array}$} & \multirow{3}{*}{$\begin{array}{l}\text { Ecological sustainability makes } \\
\text { development be accompanied by the } \\
\text { survival of ecological processes, } \\
\text { biological variety and biological } \\
\text { resources. }\end{array}$} & $\begin{array}{l}\text { Improvement and protection of the environment and } \\
\text { natural ecosystems of the area (protection of } \\
\text { biological variety and wild life habitats, ....) }\end{array}$ \\
\hline & & $\begin{array}{l}\text { Tourism development with regard to limitations and } \\
\text { natural and bio-environmental limits of the area. }\end{array}$ \\
\hline & & $\begin{array}{l}\text { Protecting ecosystems and natural systems from } \\
\text { bio - environmental pollutions. }\end{array}$ \\
\hline \multirow{2}{*}{$\begin{array}{c}\text { Social } \\
\text { sustainability }\end{array}$} & \multirow{2}{*}{$\begin{array}{l}\text { Social sustainability signifies local } \\
\text { national abilities of a community for } \\
\text { accepting tourists for a short or long } \\
\text { time, in a way that any disunity and } \\
\text { contradictions do not appear the } \\
\text { social structure of a community and } \\
\text { if there is any, it should be as less as } \\
\text { possible. }\end{array}$} & $\begin{array}{l}\text { Respect and attention to the groups such as in bound } \\
\text { tourists and local communities, who use the } \\
\text { environment, to motivate in bound and out bound } \\
\text { tourists for coming to the region. }\end{array}$ \\
\hline & & $\begin{array}{l}\text { Enhancing tourist reception ability of local } \\
\text { communities. }\end{array}$ \\
\hline \multirow{2}{*}{$\begin{array}{c}\text { Cultural } \\
\text { sustainability }\end{array}$} & \multirow{2}{*}{$\begin{array}{l}\text { Cultural sustainability is concerned } \\
\text { with the stability or compatibility of } \\
\text { a society with regard to cultural } \\
\text { criteria against the pressure made by } \\
\text { touristsculture. it pays attention to } \\
\text { the cultural impressions caused by } \\
\text { tourists . }\end{array}$} & $\begin{array}{l}\text { Consensus between developmental process and } \\
\text { cultural as well as local values of the region } \\
\text { (Respecting cultural rites and local traditions of the } \\
\text { place ) }\end{array}$ \\
\hline & & $\begin{array}{l}\text { Expanding educational and cultural plans to } \\
\text { encourage peoples participations in tourism } \\
\text { development. }\end{array}$ \\
\hline \multirow{2}{*}{$\begin{array}{l}\text { Economical } \\
\text { sustainability }\end{array}$} & \multirow{2}{*}{$\begin{array}{l}\text { Economical sustainability deals with } \\
\text { economical benefits accrued from } \\
\text { sufficient activities or affording the } \\
\text { costs of tourists presence and } \\
\text { reducing the negative effects of their } \\
\text { presence in the local community }\end{array}$} & $\begin{array}{l}\text { Carring out managing plans to encourage the } \\
\text { participation of local communities in tourism } \\
\text { development. }\end{array}$ \\
\hline & & $\begin{array}{l}\text { Enhancing the } \\
\text { of the area for more tourist attraction and } \\
\text { economical benefits. }\end{array}$ \\
\hline
\end{tabular}

Table 4. The Current Situation of the Margoon Protected Area. References: Authors

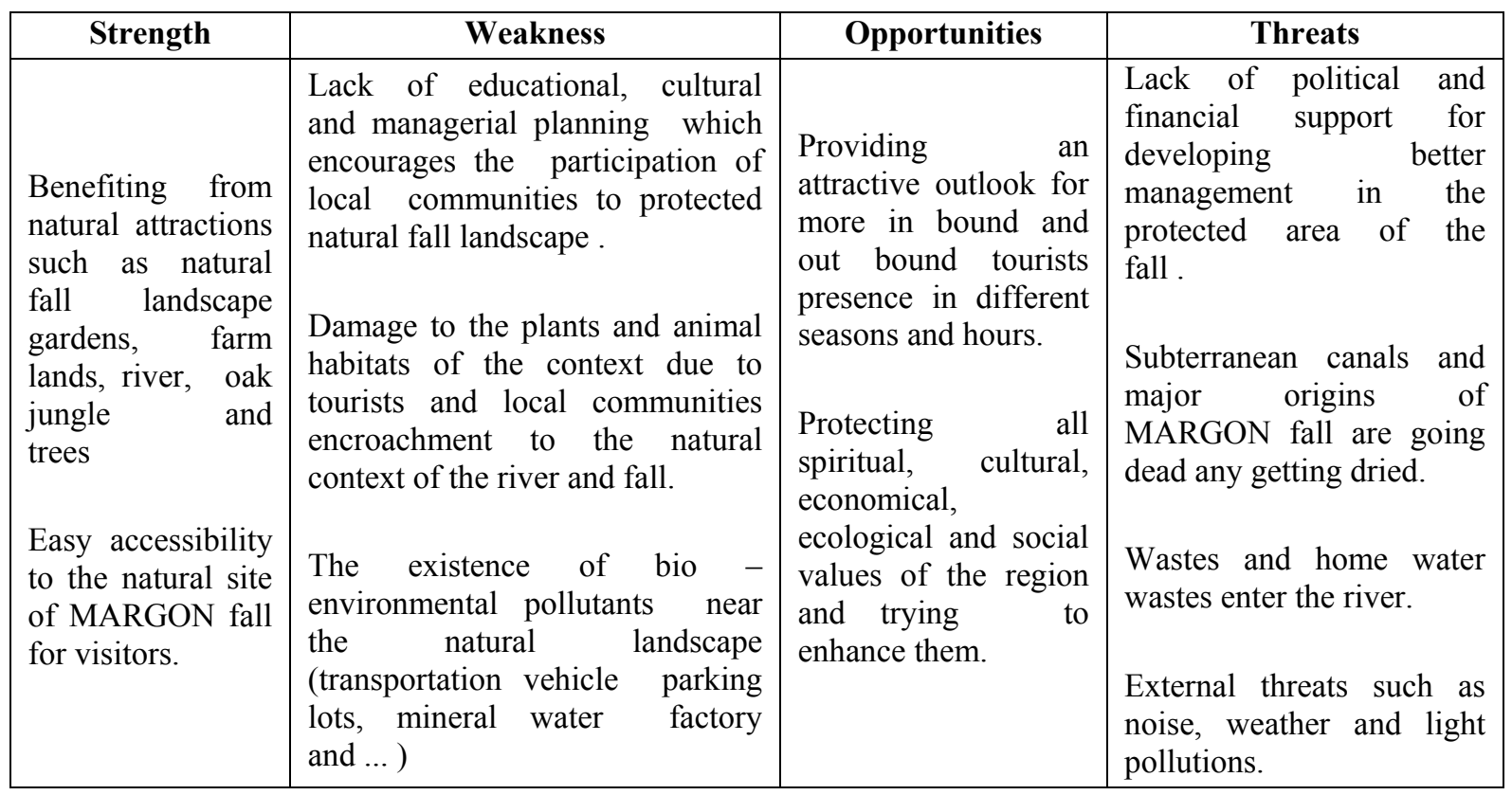


Table 5. Descriptive Statistics \& Demographic Characteristics. References: Authors

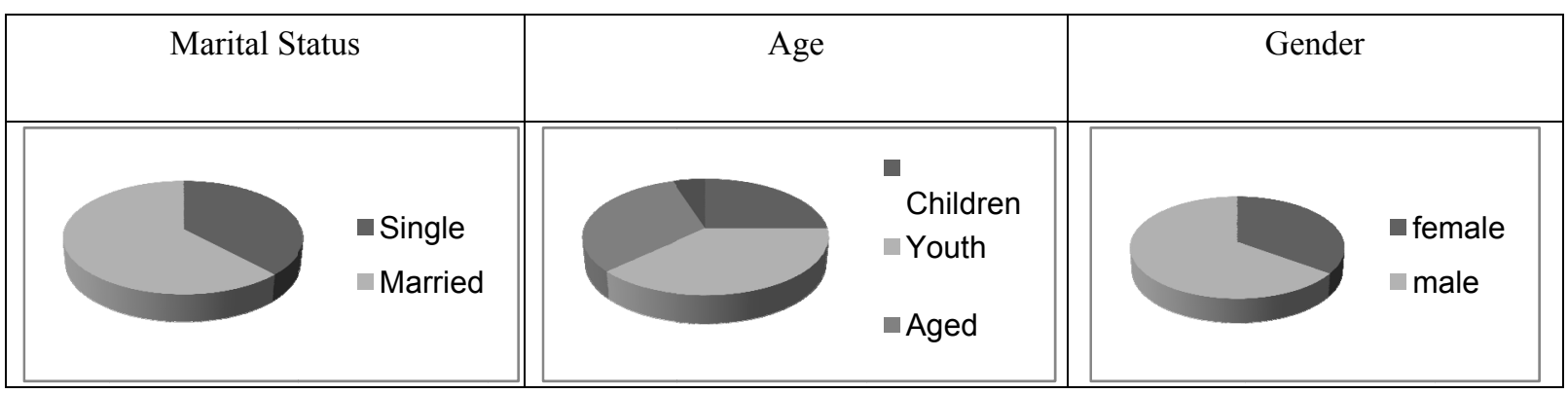

Table 6. Rate Capability between Recreational \& Educational Facilities and Services with the Natural Attraction of Margoon Protected Area. References: Authors

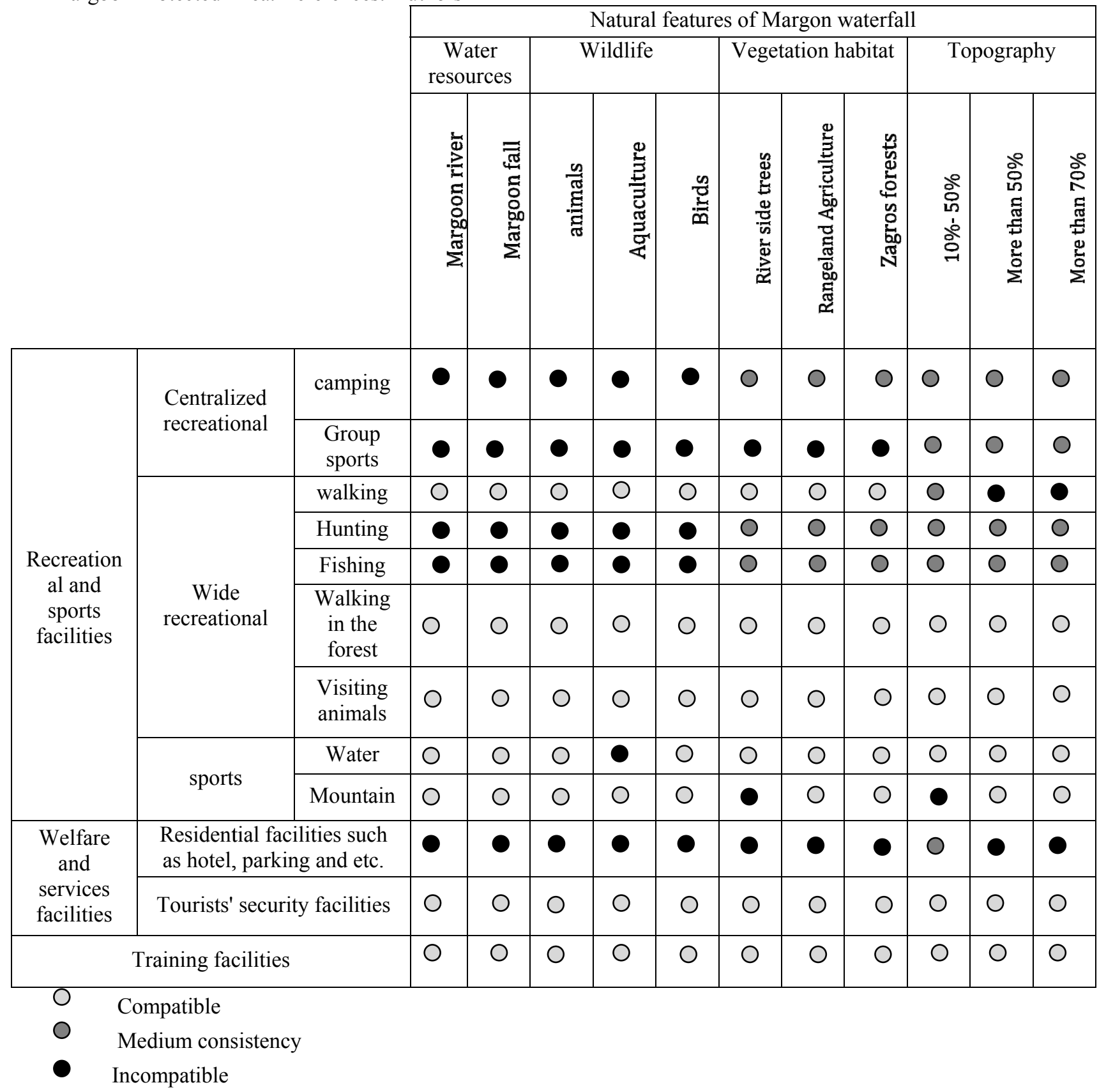


Table 7. Suggestion for Sustainable Tourism Development in the Margoon Waterfall Protected Area. References: Authors

\begin{tabular}{|c|c|c|}
\hline Aspects & \multicolumn{2}{|l|}{ Suggestions } \\
\hline \multirow{4}{*}{ Conservation } & \multicolumn{2}{|c|}{$\begin{array}{l}\text { Protecting bed from waste and waste water created by tourists and local communities through } \\
\text { promoting training programs for attracting more and more local communities and tourists } \\
\text { partnerships in protecting. }\end{array}$} \\
\hline & \multicolumn{2}{|c|}{$\begin{array}{l}\text { Tourism development according to the power and environmental capacity of natural waterfall } \\
\text { (now the presence of tourists, out of bed capacity can cause destruction of ecosystems, erosion } \\
\text { and threatening aquatic life and other biological species) }\end{array}$} \\
\hline & $\begin{array}{l}\text { Protecting natural habitats and wildlife (protection of the } \\
\text { Zagros oak forest, riverside plants ...) through applied } \\
\text { management program to control the unreasonable } \\
\text { interference Visitors in natural bed. }\end{array}$ & \\
\hline & $\begin{array}{l}\text { Since the major preferences of tourists for the presence in } \\
\text { natural waterfall bed, hunting is determined limits allowed } \\
\text { for hunting to protect wildlife distinct region is required }\end{array}$ & \\
\hline \multirow{10}{*}{ Development } & $\begin{array}{l}\text { Stabilizing natural slopes of Margon bed through promoting } \\
\text { regional vegetation. }\end{array}$ & \\
\hline & $\begin{array}{l}\text { Deleting incompatible functions and environmental } \\
\text { pollutants such as vehicles parking near natural limits of } \\
\text { Margoon waterfall site. }\end{array}$ & \\
\hline & $\begin{array}{l}\text { Creating temporary exhibits handicrafts, cultural ceremonies, } \\
\text { familiarize visitors with cultural values of the bed. }\end{array}$ & nd local music and etc in order to \\
\hline & $\begin{array}{l}\text { Emphasizing on areas with conservation values in tourists } \\
\text { notation and placing landmarks in the natural bed of } \\
\text { Margoon fall. } \\
\text { Designing recreational places according to the natural limits } \\
\text { of the bed. }\end{array}$ & \\
\hline & To facilitate pedestrian access to different parts of site. & \\
\hline & Designing specific entrance, guard posts and specific tips. & \\
\hline & Organizing night status of the region. & \\
\hline & $\begin{array}{l}\text { Prevent the destruction of forests and vegetation as the majo } \\
\text { through the upgrading of local community livelihood situation }\end{array}$ & tourism attractions of the region \\
\hline & Designed route passing according to the natural slope of the $b$ & \\
\hline & Restoring Margoon village to establish residential areas and ct & ating economic profits. \\
\hline
\end{tabular}




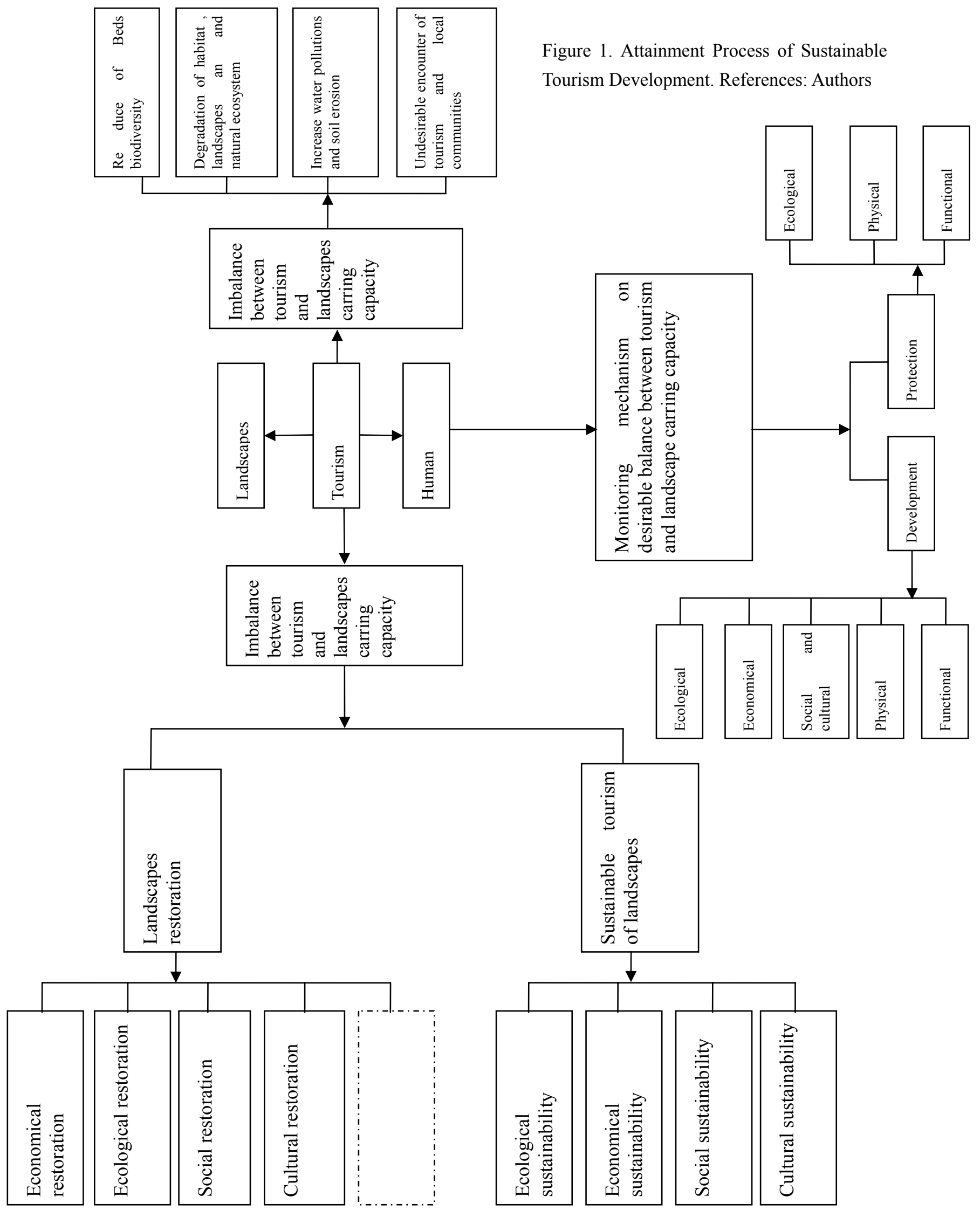




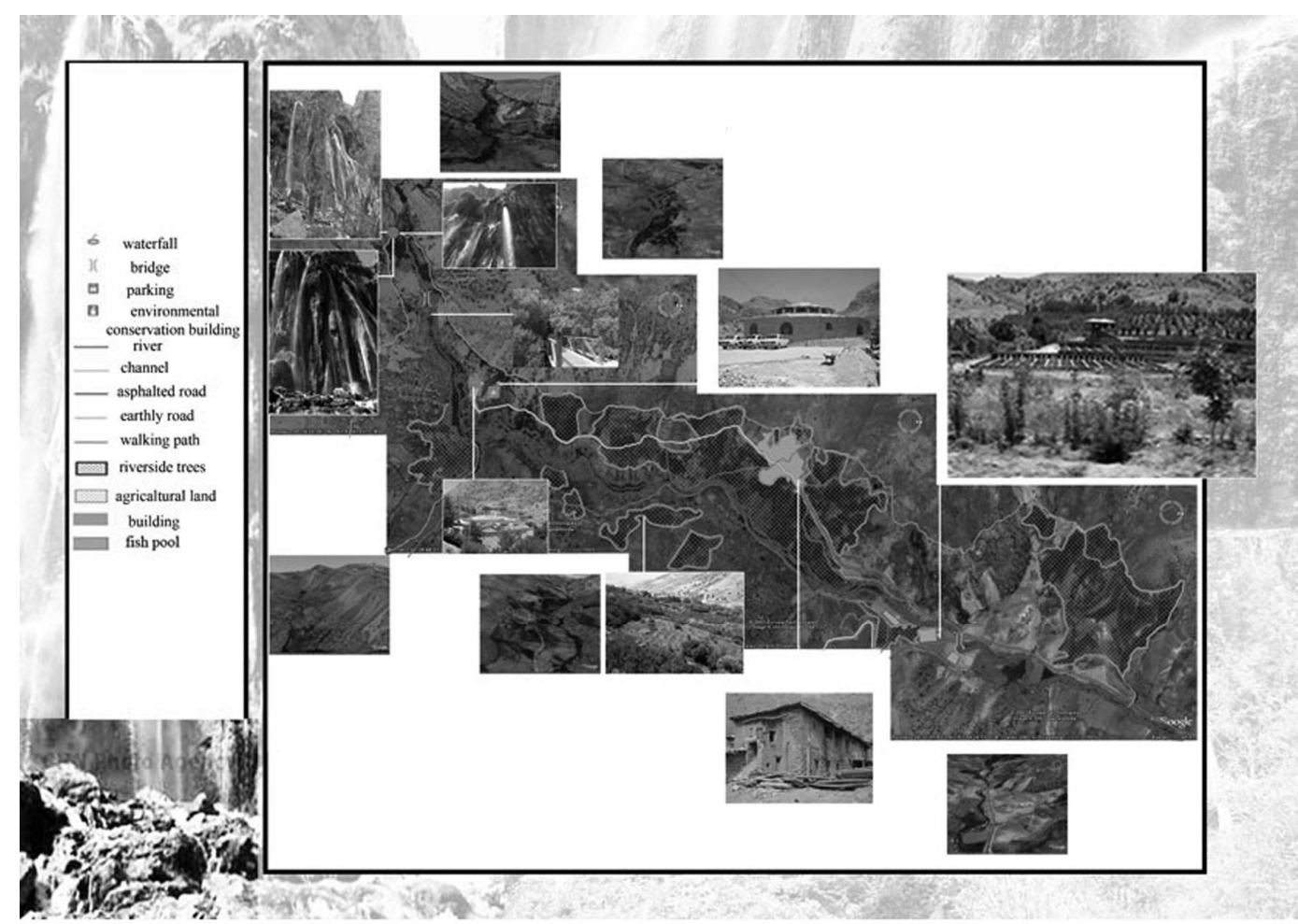

Figure 2. Current Use of the Protected Region of Margoon Waterfall. References: Authors

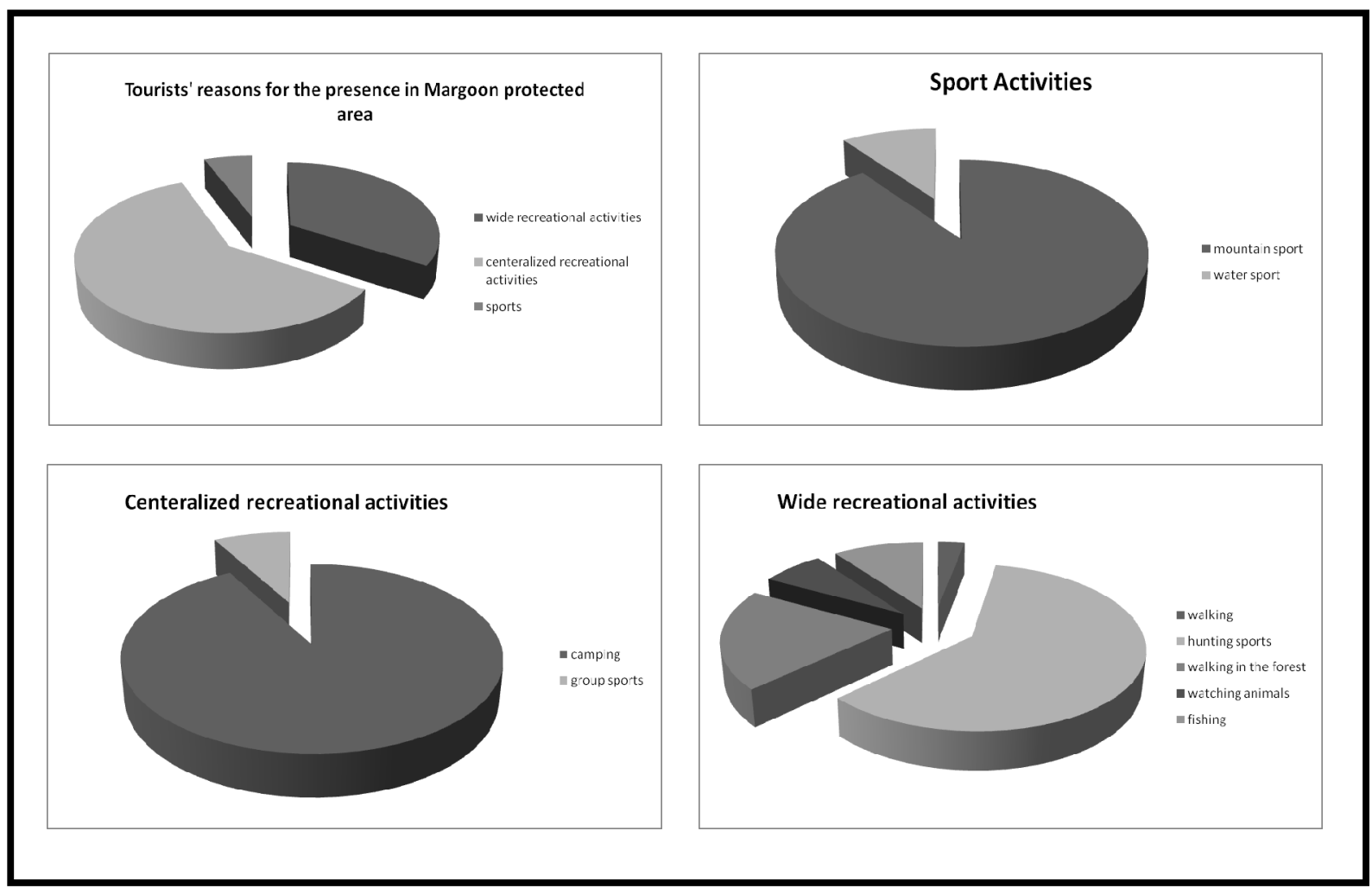

Figure 3. Tourists' Reasons for Presence in Margoon Site According to Their Ideas. References: Authors 